\title{
A Uniform Approach to Rule 11 Sanctions
}

\author{
Alan E. Untereiner
}

Rule 11 of the Federal Rules of Civil Procedure ${ }^{1}$ governs abusive tactics and frivolous pleadings, motions, or other papers submitted in federal court. Since 1983, when the Rule was strengthened to encourage sanctioning, judges increasingly have sanctioned litigants advancing far-fetched claims, or filing papers based on hasty research into the facts or the law. ${ }^{2}$ In just under five years, Rule 11 has produced over 1,000 cases ${ }^{3}$ and a flurry of academic commentary. ${ }^{4}$ Rule 11 is transforming the conduct of litigation in the federal courts. ${ }^{5}$

Critics of amended Rule 11 argue that it chills creative advocacy, ${ }^{6}$ generates wasteful satellite litigation, ${ }^{7}$ interferes with the attorney-client rela-

1. For the relevant text of Rule 11, see infra note 24 .

2. See, e.g., Heimbaugh v. City of San Francisco, 591 F. Supp. 1573 (N.D. Cal. 1984) (recent law school graduate alleged equal protection violation because police forced students playing softball in city park to vacate hardball diamond).

3. Joseph, The Trouble with Rule 11, 73 A.B.A. J., Aug. 1, 1987, at 87, 88. Since publication of the opinion is itself a form of reputational sanction, many cases go unreported or are available only on LEXIS. See Chrein, The Actual Operation of Amended Rule 11, 54 ForDHAM L. REv. 13, 16 (1985).

4. See sources cited infra notes 6-15. For empirical studies of Rule 11, see NEw York STATE Bar Ass'n, Report of the Committee on Federal Courts: Sanctions and Attorneys' Fees (1987) [hereinafter New York Report]; S. Kassin, AN EMpIrical Study of Rule 11 Sanctions (Federal Judicial Center 1985).

5. See Schwarzer, Rule 11 Revisited, 101 Harv. L. Rev. 1013, 1013 (1988) ("Rule 11 has become a significant factor in civil litigation, with an impact that has likely exceeded its drafters' expectations."). Judges, too, have begun to note the impact of Rule 11 cases on their dockets. See, e.g., Szabo Food Serv. v. Canteen Corp., 823 F.2d 1073, 1086 (7th Cir. 1987) (Cudahy, J., concurring in part and dissenting in part) ("WW]e now seem almost at the point of saying that the main question before the court is not 'Are you right?' but 'Are you sanctionable?" "), cert. dismissed, 108 S. Ct. 1101 (1988); Eastway Constr. Corp. v. City of New York, 821 F.2d 121, 124 (2d Cir.) (Pratt, J., dissenting) (referring to "new 'Era of Sanctions' "), cert. denied, 108 S. Ct. 269 (1987).

6. Eastway Constr. Corp. v. City of New York, 637 F. Supp. 558, 574-75 (E.D.N.Y. 1986) (Weinstein, C.J.), modified, 821 F.2d 121 (2d Cir.), cert. denied, 108 S. Ct. 269 (1987); Nelken, Sanctions Under Amended Federal Rule 11-Some "Chilling" Problems in the Struggle Between Compensation and Punishment, 74 Gro. L.J. 1313, 1338-43 (1986); Note, Plausible Pleadings: Developing Standards for Rule 11 Sanctions, 100 HARv. L. Rev. 630, 632 (1987). But see FED. R. Crv. P. 11 advisory committee note, reprinted in 97 F.R.D. 165, 199 (1983) (note to 1983 Amendments) [hereinafter Advisory Notes] ("The rule is not intended to chill an attorney's enthusiasm or creativity in pursuing factual or legal theories.").

7. Rule 11 is aimed partly at relieving federal courts of the burden of processing unnecessary, frivolous claims. Some commentators note that the Rule has generated enough ancillary litigation over the applicability of sanctions (so-called "satellite litigation") to undercut the goal of reducing the courts' workload. See, e.g., Federal Procedure Comm., ABA, Sanctions: Rule 11 and OTHER Powers 15-16 (2d ed. 1988) [hereinafter ABA RePORT]. But see Levin \& Sobel, Achieving Balance 
tionship, ${ }^{8}$ sours relations between opposing counsel ${ }^{9}$ and between bench and bar, ${ }^{10}$ overdeters particular types of claimants, ${ }^{11}$ and conflicts with the liberal pleading regime of the Federal Rules. ${ }^{12}$ Supporters of the Rule, however, contend that it deters much frivolous litigation (thereby conserving judicial resources), ${ }^{13}$ compensates the victims of vexatious litigation, and educates the bar about appropriate standards of conduct. ${ }^{14}$

A problem recognized by both supporters and critics has been Rule 11's inconsistent application. ${ }^{15}$ Varying judicial attitudes-in particular, disagreement over the primary purpose of Rule $11^{16}$-and the absence of standards or guidelines for deciding both whom to sanction ${ }^{17}$ and what sanction is appropriate have produced inconsistent outcomes. ${ }^{18}$ Nonuniform sanctions have created an impression of arbitrariness, ${ }^{19}$ as

in the Developing Law of Sanctions, 36 CATH. U.L. Rev. 587, 606-08 (1987) (listing five factors that reduce danger of satellite litigation).

8. Nelken, supra note 6, at 1343-45. But cf. Comment, Rule 11 Sanctions, 48 Mont. L. Rev. $119,130-132$ (1987) (attorney-client privilege and work product protection usually will not be threatened by Rule 11 proceedings).

9. Weiss, A Practitioner's Commentary on the Actual Use of Amended Rule 11,54 Fordham L. REv. 23, 24 (1985).

10. Schwarzer, Sanctions Under the New Federal Rule 11-A Closer Look, 104 F.R.D. 181, 183 (1985).

11. See, e.g., Note, supra note 6, at 631 (civil rights plaintiffs). Recent empirical data demonstrates that civil rights and employment discrimination plaintiffs are sanctioned disproportionately. Vairo, Rule 11: A Critical Analysis, 118 F.R.D. 189, $200-01$ (1988); see also LaFrance, Federal Rule 11 and Public Interest Litigation, 22 VAL. U.L. REv. 331, 333 (1988) (arguing that Rule 11 is "antithetical to public interest litigation").

12. Note, supra note 6 . One critic has gone so far as to question the power of judicial rulemakers to impose mandatory sanctions. Burbank, Sanctions in the Proposed Amendments to the Federal Rules of Civil Procedure: Some Questions About Power, 11 HofsTra L. Rev. 997, 1008-09 (1983).

13. See, e.g., Comment, supra note 8, at 119; Note, Litigant Responsibility: Federal Rule of Civil Procedure 11 and Its Application, 27 B.C.L. Rev. 385, 406 (1986).

14. Levin \& Sobel, supra note 7, at 594. One commentator has suggested that amended Rule 11 is not stringent enough. See Parness, Groundless Pleadings and Certifying Attorneys in the Federal Courts, 1985 Utah L. Rev. 325.

15. See, e.g., Schwarzer, supra note 5, at 1015 ("In interpreting and applying rule 11, the courts have become a veritable Tower of Babel."); Note, supra note 6, at 638-41; Grosberg, The Rule 11 Debate: Circuit Gives No Guidance in Eastway, Nat'l L.J., Sept. 14, 1987, at 19, col. 4; Joseph, supra note 3, at 89; see also infra Section III-A.

16. See infra Section II-B.

17. The secondary literature on amended Rule 11 has not analyzed the problem of whom to sanction, discussing it only briefly in the context of broader surveys of the Rule. See, e.g., Vairo, supra note 11, at 227-28; Note, supra note 13, at 402-03; Note, The Dymamics of Rule 11: Preventing Frivolous Litigation by Demanding Professional Responsibility, 61 N.Y.U. L. Rev. 300, 331 n.228 (1986) [hereinafter Note, The Dynamics of Rule 11]. But see Note, The Intended Application of Federal Rule of Civil Procedure 11: An End to the "Empty Head, Pure Heart" Defense and a Reinforcement of Ethical Standards, 41 VAND. L. REv. 343, 353-54, 376-77 (1988) [hereinafter Note, Intended Application] (arguing that in most cases courts should sanction attorney alone).

18. Thomas v. Gapital Sec. Servs., 836 F.2d 866, 871 (5th Gir. 1988) (en banc) (Rule 11 decisions "have not always been consistent, producing confusion among the bench and bar, as well as inequitable results.").

19. See S. Kassin, supra note 4 , at 45 (finding willingness among judges to sanction but limited "clarity and uniformity" in Rule's application); Grosberg, Illusion and Reality in Regulating Lawyer Performance: Rethinking Rule 11, 32 VILL. L. Rev. 575, 587-88 \& nn. 42-43 (1987); see also Eastway Constr. Corp. v. City of New York, 821 F.2d 121, 126 (2d Gir.) (Pratt, J., dissenting) (noting "apparent disparities, even capriciousness, that now seem to characterize much of rule 11 jurisprudenre"). cert. denied, 108 S. Ct. 269 (1987); Weiss, supra note 9, at 26 ("Many judges ... 
judges and jurisdictions with different sanctioning records ${ }^{20}$ have imposed varying sanctions on similarly situated violators. ${ }^{21}$ Lack of uniformity has undercut Rule 11's goals. ${ }^{22}$ More fundamentally, judges and commentators have tended to view Rule 11 as involving discrete and unconnected judicial determinations.

This Note proposes an integrated approach to Rule 11 sanctions that will promote consistency in sanctioning practice. Section I briefly describes the Rule and its 1983 amendments. Section II proposes an analytical framework for understanding the three interpretive questions posed by Rule 11-when is the Rule violated, who should be sanctioned, and what sanction is appropriate-and demonstrates that these questions are inseparably linked. It then argues that judges should bear in mind both this conceptual framework and the primary purpose of Rule 11-deterring frivolous litigation-when making sanction determinations. Section III demonstrates how judges have failed to understand the interconnectedness of Rule 11's interpretive questions, producing failures in the Rule's application. This Section also explains why appeals courts have failed to bring uniformity to Rule 11 case law. Section IV sets forth the benefits greater uniformity would bring, and Section $\mathrm{V}$ offers guidelines, based on the developing case law, to aid judges in answering the Rule's most neglected questions: whom to sanction and what sanction to impose.

\section{The 1983 Amendments to Rule 11}

Rule 11 was originally passed along with the other Federal Rules of Civil Procedure in 1938, but judges employed it infrequently. ${ }^{23}$ In response to growing concern over frivolous lawsuits and abusive tactics in federal court, Rule 11 was amended in 1983, a move which broadened its scope significantly. ${ }^{24}$ The standards for sanctionable conduct were en-

have deep-seated biases and are out to get particular lawyers. And boy, Rule 11 is some tool to do it with.").

20. According to Professor Grosberg, in the first two years under amended Rule 11, 12.2\% of all Rule 11 opinions in which sanctions were imposed were written by three (of 684 sitting) federal judges: Judges Shadur (N.D. Ill.), Schwarzer (N.D. Cal.), and Haight (S.D.N.Y.). Grosberg, supra note 19 , at 587 n.42.

21. Parness, The New Method of Regulating Lawyers: Public and Private Interest Sanctions During Civil Litigation for Attorney Misconduct, 47 LA. L. Rev. 1305, 1306, 1313 (1987).

22. See infra Sections II-B \& IV.

23. Risinger, Honesty in Pleading and Its Enforcement: Some "Striking" Problems with Federal Rule of Civil Procedure 11, 61 MinN. L. Rev. 1, 34-37 (1976) (only 23 reported cases between 1938 and 1976 in which sanctions sought by party).

24. The relevant text of Rule 11 of the Federal Rules of Civil Procedure, with italicized sections representing 1983 additions, is as follows:

The signature of an attorney or party constitutes a certificate by the signer that the signer has read the pleading, motion, or other paper; that to the best of the signer's knowledge, information, and belief formed after reasonable inquiry it is well grounded in fact and is warranted by existing law or a good faith argument for the extension, modification, or reversal of existing law, and that it is not interposed for any improper purpose, such as to harass or to cause unnecessary delay or needless increase in the cost of litigation. . . . If a pleading, motion, or other paper is signed in violation of this rule, the court, upon motion or upon its 
larged and made more objective. ${ }^{25}$ In addition, the Rule was changed to require judges to impose sanctions once a violation was found. Judges were, however, given greater leeway to impose different types of sanctions and to sanction clients or attorneys. The 1983 amendments were designed to increase the application of what had been an underused rule. ${ }^{28}$

Most commentators have hailed the wide latitude ${ }^{27}$ delegated to trial judges to fashion appropriate sanctions and to decide whom to sanction. ${ }^{28}$ Because of her proximity to the offending conduct, the trial judge is considered best equipped to apportion responsibility for frivolous submissions and to tailor sanctions to fit particular violations. Appealing for its suggestion of careful, individualized judgments, this argument nonetheless overlooks the problems caused by both differences among judges ${ }^{28}$ and the systemic effect of such highly discretionary, individualized judgments: a lack of overall uniformity in Rule 11 sanctions. $^{30}$

\section{A NeW Gonceptual Framework for Understanding RULE 11}

Rule 11 is often analyzed as identifying three "prongs" of sanctionable conduct: legally frivolous, factually frivolous, and motivated by an improper purpose. This way of analyzing the Rule reflects a preoccupation with the determination of when conduct is sanctionable. A more useful conceptual framework for understanding Rule 11 considers two additional interpretive questions and focuses on the primary goal of the Rule-deterrence of frivolous litigation.

own initiative, shall impose upon the person who signed it, a represented party, or both, an appropriate sanction, which may include an order to pay to the other party or parties the amount of the reasonable expenses incurred because of the filing of the pleading, motion, or other paper, including a reasonable attorney's fee.

Fed. R. Civ. P. 11, reprinted in 2A J. Moore, J. LuCas \& G. Grotheer, Moore's Federal. Practice II 11.01 (2d ed. 1987).

25. Amended Rule 11 established three prongs of sanctionable conduct: (1) insufficient legal basis, (2) insufficient factual basis, and (3) improper purpose.

26. Advisory Notes, supra note 6, at 198.

27. Both the broadened discretion to set the type and target of sanctions, and the narrowed discretion to impose a sanction once a violation is found, were aimed at encouraging judges to impose sanctions. These changes in judicial discretion were not an independent goal of the 1983 amendments, but rather a means to achieve greater enforcement and thus greater deterrence. The drafters apparently failed to appreciate that there might be little difference between finding no violation under the old Rule, and finding a violation but imposing a minimal sanction under the new Rule.

28. See, e.g., A. Miller, The August 1983 Amendments to the Federal Rules of Civil Procedure: Promoting Effective Case Management and Lawyer Responsibility 17 (Federal Judicial Center 1984) (characterizing "appropriate" sanction language as "judge's safety valve" given that sanctions must be imposed); Nelken, supra note 6, at 1321-23.

29. See infra notes 40-43 and accompanying text.

30. Cf. Friendly, Indiscretion About Discretion, 31 EMORY L.J. 747, 756-58, 768 (1982) (noting benefits of broader appellate review of discretionary decisions). 


\section{A. Interpretive Questions Posed by the Rule}

Rule 11 raises three interconnected interpretive issues for the court: (1) When has sanctionable conduct occurred? (2) Who should be sanctioned-attorney, client, or both? (3) What sanction is appropriate? Most commentary and case law under Rule 11 have focused on the threshold determination of when conduct is sanctionable. ${ }^{31}$ This is not surprising, since the first question determines the circumstances under which the Rule applies. ${ }^{32}$

Courts have not realized the extent to which the latter two questions of whom to sanction and what sanction is appropriate are related to the Rule's effective operation. Rule 11's deterrence goals will not be achieved if judges, once they discover sanctionable conduct, impose an inappropriate type or size of sanction, or sanction the wrong party. Appellate courts are only beginning to realize that a trial judge opposed to Rule 11 's mandate of imposing sanctions can undercut the Rule's purposes by imposing a minuscule sanction. ${ }^{33}$

\section{B. The Confusion over Rule 11's Purpose}

\section{Compensation, Deterrence, and Punishment}

When discussing the purposes behind Rule 11, courts and commentators mention compensation, ${ }^{34}$ deterrence, ${ }^{36}$ and punishment. ${ }^{36}$ Unfortunately, few have gone beyond a mere invocation of one or more purposes to examine the connection between the Rule's primary purpose and its effectiveness.

\section{The Extent and Effect of Disagreement over Primary Purpose}

Even if judges grasp the interconnectedness of Rule 11's interpretive questions, nonuniformity in sanctioning will persist unless consensus is

31. See, e.g., Grosberg, supra note 19; Note, supra note 13; Note, Reasonable Inquiry Under Rule 11-Is the Stop, Look, and Investigate Requirement a Litigant's Roadblock?, 18 IND. L. REv. 751 (1985).

32. Because the first question has been deemed one of law, it has been reviewed more often and under a broader standard of review by courts of appeals. See cases cited infra note 78.

33. See, e.g., Thomas v. Capital Sec. Servs., 836 F.2d 866 (5th Cir. 1988) (en banc) (once violation found, some sanction must be imposed), overruling Bell v. Bell, 6 Fed. R. Serv. 3d (Callaghan) 1084 (5th Cir. 1987).

34. Compensation refers to the financial reimbursement, usually of attorneys' fees, to the party opposing the frivolous submission.

35. Deterrence refers to both the expected inhibiting effect of actual sanctions on violators (specific deterrence) and the general restraining effect of the threat of sanctions on potential violators (general deterrence). Robinson, A Sentencing System for the 21st Century?, 66 TEx. L. REv. 1, 6 n.21 (1987).

36. Punishment implies moral blameworthiness and translates into sanctions commensurate with the degree of culpability (including the violator's mental state). Id. at 6-7 \& n.20. Yet Rule 11 violations can occur when submissions violate an objective, reasonable attorney standard. Although the concept of punishment often involves penalizing commensurately to the degree of harm caused, this view would bring punishment close to the idea of compensation. 
reached over the Rule's overarching purpose. When a rule cannot, on its face, guide judicial determinations, courts look behind the rule to its purpose; a lack of consensus over purpose will produce variable outcomes. This variance is accentuated because the Rule's purposes are often in conflict. ${ }^{37}$ While any particular sanction can further all three purposes in varying degrees, ${ }^{38}$ situations do arise in which different purposes point the decisionmaker in different directions. In a particular instance, compensation may require a very different sanction from specific deterrence or punishment. Thus, in cases of conflict, one purpose must trump the others. ${ }^{39}$

Judges have different conceptions of Rule 11's primary purpose, as several empirical studies indicate. ${ }^{40} \mathrm{~A}$ judge's view about primary purpose has been shown to directly affect her willingness to impose sanctions, ${ }^{41}$ and may even influence her determination of the size, type, and target of sanctions. ${ }^{42}$ Disagreement over the purpose of Rule 11 accounts for wide

37. Cf. W. LaFave \& A. Scotr, Criminal Law 27 (2d ed. 1986) (noting need to determine priority and relationship of potentially conflicting aims of criminal law).

38. A monetary sanction, for example, will in some way further all three aims; a nonmonetary sanction will not compensate, however. See also Nelken, supra note 6, at 1314, 1323-25. Although Nelken accurately describes the interrelation of deterrence, compensation, and punishment, she does not consider deterrence to be a possible focus of Rule 11. Perhaps this is because she only considers general deterrence. Similarly, a student Note on the deterrence rationale behind analogous discovery sanctions did not distinguish between specific and general deterrence but focussed on the latter. See Note, The Emerging Deterrence Orientation in the Imposition of Discovery Sanctions, 91 HARV. L. REv. 1033 (1978).

39. Commentators on sentencing reform have realized the need to stress a single, overriding purpose behind criminal sentences. See von Hirsch, The Sentencing Commission's Functions in ThE Sentencing Commission and Its Guidelines 3, 9-10 (A. von Hirsch, K. Knapp \& M. Tonry eds. 1987); Robinson, supra note 35, at 6-7; see also W. LAFAvE \& A. ScoTt, supra note 37, at 27 (same in criminal law generally).

40. See S. Kassin, supra note 4, at 29; NEw YoRk REPORT, supra note 4, at 23. When asked about Rule 11 's primary purpose, $59.4 \%$ of district judges answered deterrence, while $19.6 \%$ said punishment and $21 \%$ compensation. S. KASSIN, supra note 4, at 29-32. Kassin's study involved a survey of 292 active federal district court judges. Judges were asked both to answer general questions about Rule 11 and to respond to various hypothetical fact situations. The study did not distinguish between specific and general deterrence.

Despite its more recent date, the New York Bar Association's Report is limited, imprecise, and generally less useful in determining judicial views about Rule 11's purpose than is Kassin's 1985 national study. See NEw YORK REPORT, supra note 4, at 10, A7-A9.

41. See S. KASsin, supra note 4, at 31. Judges who viewed compensation as Rule 11's key objective imposed sanctions $61.1 \%$ of the time in the hypotheticals. By contrast, those who saw Rule 11 as aimed at deterrence imposed sanctions only $48.5 \%$ of the time. The lowest rate occurred among punishment-oriented judges: $34.6 \%$. One would thus expect district judges who believe that compensation is Rule 11's primary purpose to impose sanctions almost twice as often as judges who focus on punishment.

42. Although Kassin's research indicated that compensation-oriented judges might grant higher attorneys' fee awards than punishment-oriented judges (with deterrence-oriented judges in the middle), "[t]he study does not provide a clear answer" on this issue, $i d$. at 32 , because the size of the subgroup relevant to this issue was too small. Id. at 30 n.63.

Judges who favor compensatory goals would be more likely to impose monetary sanctions and to set the sanction amount close to defendant's expenses. To ensure compensation, these judges might also favor joint and several sanctions against the plaintiff and her attorney. By contrast, judges who stress deterrence may be less likely to impose monetary sanctions, since nonmonetary ones can more effectively deter. In calculating monetary sanctions, deterrence-oriented judges might also be less likely to start with expenses incurred. These judges would be more likely to adjust a monetary sanction to an amount that deters the offending attorney or client. Instead of handing down joint and several sanc- 
disparities in sanctioning practice. ${ }^{43}$

\section{Deterrence as the Primary Goal}

To reduce disparities in sanctioning, judges should consider deterrence to be the primary goal of Rule 11. The Advisory Committee Notes mention only deterrence as the purpose behind the 1983 amendments. ${ }^{44}$ In addition, most judges ${ }^{45}$ and commentators ${ }^{46}$ agree that deterrence is the Rule's primary goal. ${ }^{47}$ Finally, as a procedural rule, Rule 11 is aimed at streamlining the process of litigation by eliminating-i.e. deterring-frivolous submissions. ${ }^{48}$

While compensation and punishment may be secondary aims of Rule 11 , viewing either one as the Rule's primary purpose would be problem-

tions, judges who stress deterrence might apportion sanctions depending upon whether the party needing deterrence is attorney or client. A final set of judges, those who view the Rule as primarily aimed at punishment, might sanction only the most egregious violators, fashion the sanction to fit the degree of bad faith or culpability, and avoid joint and several sanctions unless both sanctioned individuals have demonstrated culpable behavior.

43. NEw YORK REPORT, supra note 4, at 15 ("Examination of the reported cases reveals a great deal of inconsistency as to whether there has been a Rule 11 violation, and if so, what sanction should be imposed. Part of the reason for this seems to be that the courts have not yet agreed on the purpose or purposes of Rule 11."); Vairo, supra note 11, at 203.

44. S. KASSIN, supra note 4, at 29; Grosberg, supra note 19, at 584-85; Schwarzer, supra note 5, at 1020; see Advisory Notes, supra note 6, at 199-200 ("The word 'sanctions' in the caption ... . stresses a deterrent orientation in dealing with improper pleadings, motions or other papers."); id. at 198 (predicting that enforcement of Rule will "discourage dilatory or abusive tactics and help to streamline the litigation process by lessening frivolous claims or defenses"); see also Letter of Transmittal from Walter R. Mansfield, Chairman of the Advisory Committee on Civil Rules (Mar. 9, 1982), reprinted in 97 F.R.D. 190, 192 (1983) (mandatory sanctions "a healthy deterrent"); Eastway Constr. Corp. v. City of New York, 637 F. Supp. 558, 564 (E.D.N.Y. 1986) (Weinstein, C.J.), modified, 821 F.2d 121 (2d Gir.), cert. denied, 108 S. Ct. 269 (1987).

Confusion has perhaps resulted because the text of Rule 11 indicates that an appropriate sanction "may include an order to pay ... the reasonable expenses incurred because of the frivolous submission], including a reasonable attorney's fee." FED. R. Crv. P. 11. This language only reminds judges that monetary sanctions may be an appropriate sanction, and does not express a general preference for compensatory sanctions. See also Schwarzer, supra note 5, at 1020 (contrasting Rule 11 to Rule 37's explicit authorization of fee shifting, and arguing that "when the drafters of the rules meant to provide for fee shifting, they knew how to do it").

45. See supra note 40 and accompanying text.

46. Schwarzer, supra note 5 , at 1020 n.31.

47. See, e.g., In re Yagman, 796 F.2d 1165, 1184 (9th Cir.) (deterrence "paramount" and "overriding" goal of Rule), amended, 803 F.2d 1085 (9th Cir. 1986), cert. denied, 108 S. Ct. 450 (1987). For examples of judges and commentators who argue that the Rule's focus should be either compensation or punishment, see Eastway, 821 F.2d at 124-26 (Pratt, J., dissenting) (compensation rationale); In re TCI Ltd., 769 F.2d 441, 446 (7th Cir. 1985) (Easterbrook, J.) (suggesting that compensation is major, if not primary, rationale for Rule 11 sanctions); Miller \& Culp, Litigation Costs, Delay Prompted the New Rules of Civil Procedure, Nat'l L.J., Nov. 28, 1983, at 24, 34, col. 2 ("Although denominated a sanction provision, in reality it is more appropriately characterized as a cost-shifting technique."); Note, The Dynamics of Rule 11, supra note 17, at 329 (arguing that purpose is primarily punitive). See generally Grosberg, supra note 19, at 586-87 ("The stated objective of Rule 11 was to deter frivolous litigation and, thereby lessen the pressures on court dockets. Courts have often applied Rule 11, however, having in mind the secondary and unstated objectives of penalizing the offending lawyer and compensating the victim of needless litigation."); Nelken, supra note 6, at 1323-25 (arguing that two divergent views have emerged regarding purpose: compensation and punishment, with deterrence playing role in both views).

48. Grosberg, supra note 19 , at $630-31$. 
atic. Several commentators have questioned the authority of the judiciary under the Rules Enabling Act to promulgate a procedural rule aimed at shifting costs but not requiring "bad faith."48 A stress on compensation would also undercut the traditional American Rule, which requires litigants to bear only their own expenses and serves as a guarantor of access in American courts. ${ }^{\text {s0 }}$ An emphasis on punishment as a primary purpose might raise similar doubts about faithfulness to the Rules Enabling Act. ${ }^{\text {s1 }}$ A punitive focus is inappropriate for a rule that mandates sanctions under an objective standard but does not require bad faith. Finally, a focus on punishment would necessitate extensive procedural safeguards for violators. ${ }^{\text {s2 }}$

\section{Specific and General Deterrence as Guides To Sanctioning}

Translating the focus on deterrence into a guide to judicial action is a complicated task. A key distinction must be maintained between the purpose of Rule 11 and the purpose(s) of any particular sanction imposed under the Rule. ${ }^{\mathrm{J3}}$ The purpose of Rule 11 itself would seem to be general deterrence: The Rule's existence serves as a general threat to discourage lawyers and litigants from engaging in prohibited conduct. ${ }^{54}$ On the other hand, the purpose of any particular sanction is primarily specific deter-

49. See Burbank, supra note 12 (questioning judiciary's power to apply either mandatory sanctions or sanctions for mere negligence under amended Rule 11); Grosberg, supra note 19, at 584 \& n.28, 646-47. According to Professor Nelken, the compensation approach "ignores serious questions about the limits of the Supreme Court's rulemaking power." Nelken, supra note 6, at 1324 n.70; see also Alyeska Pipeline Serv. Co. v. Wilderness Soc'y, 421 U.S. 240, 260 (1975) (Congress has not "extended any roving authority to the Judiciary to allow counsel fees as costs or otherwise whenever the courts might deem them warranted."). See generally Roadway Express, Inc., v. Piper, 447 U.S. 752, 765-66 (1980) (noting bad faith exception to American Rule).

50. Schwarzer, supra note 5 , at 1020 ("[T]o attribute a broad fee-shifting rationale to rule 11 is contrary to the American Rule; fee shifting ought not to be undertaken without clear authority."). Professor Vairo has argued that a focus on fee-shifting unduly encourages Rule 11 motions, thereby souring relations among attorneys and exacerbating the problem of satellite litigation. Vairo, supra note 11, at 204, 233.

51. See Grosberg, supra note 19 , at $584 \&$ n.28 (questioning whether punishment of abusive lawyers is proper procedural concern or within Supreme Court's rulemaking power under Rules Enabling Act).

52. If punitive in nature, monetary Rule 11 "fines" might assume a criminal character and, if they exceeded $\$ 500$, require additional procedural safeguards, such as the right to jury trial. Schwarzer, supra note 10, at 202; see Donaldson v. Clark, 819 F.2d 1551, 1558-61 (11th Cir. 1987) (en banc) (discussing procedural safeguards required by due process guarantee). Perhaps because of the Advisory Committee's insistence that satellite litigation be avoided whenever possible, see Advisory Notes, supra note 6 , at 201, these due process safeguards often have been disregarded. See Comm. on Fed. Courts, Procedural Rights of Attorneys Facing Sanctions, 40 RECoRD 313, 313-16 \& n.11 (1985).

53. See, e.g., Rawls, Two Concepts of Rules, in Theories of ErHics 144 (P. Foot ed. 1977) (developing distinction between justifying whole practice and justifying particular action under it).

54. The Supreme Court has analogously endorsed general deterrence as a proper goal of discovery sanctions under Rule 37. National Hockey League v. Metropolitan Hockey Club, Inc., 427 U.S. 639, 643 (1976) (per curiam); Note, supra note 38, at 1047. 
rence. ${ }^{\mathrm{JS}}$ A sanction is actually imposed only when general deterrence (via the threat of sanctions) has failed.

For general deterrence to be achieved, Rule 11's threat of sanctions must be credible. Sanctions must be imposed when violations occur; this appears to be happening with greater frequency. As for the size of sanctions, general deterrence normally will be furthered in proportion to the severity of the sanction. ${ }^{56}$ Yet Rule 11 operates against the backdrop of legitimate litigation activity: Choosing the most severe sanction in each case would discourage or "chill" legitimate lawsuits and valid litigation techniques. ${ }^{57}$ In addition, massive sanctions could, in an individual case, go well beyond the needs of specific deterrence.

What is needed, then, is a more uniform approach to imposing and calculating individual sanctions-one that takes into account the differential need to specifically deter-so that the general deterrent aim is achieved without overdeterrence. Specific deterrence should be the guiding principle in the imposition of individual Rule 11 sanctions. ${ }^{58}$ Of course, sanctions can also serve the secondary goals of compensation and punishment, but these aims must give way when they conflict with specific deterrence.

\section{The Gurrent Failure of Rule 11's Application}

\section{A. Failures in Trial Court Application}

The question of when conduct is sanctionable is, notably, one area of Rule 11 jurisprudence that enjoys considerable uniformity ${ }^{89}$ Courts have

55. Several court have recognized the Rule's specific deterrence aim. See Brown v. Federation of State Medical Bds. of the United States, 830 F.2d 1429, 1438 (7th Cir. 1987) (recognizing specific and general deterrence goals); In re Yagman, 796 F.2d 1165, 1183 (9th Gir.) (same), amended, 803 F.2d 1085 (9th Cir. 1986), cert. denied, 108 S. Ct. 450 (1987); see also Vairo, supra note 11, at 203 ("T The rule is designed to achieve a specific deterrent effect.").

56. F. Zimring \& G. Hawkins, Deterrence: The Legal Threat in Crime Control 194-95 (1976). Yet severity of sanction alone is no guide; it may be less important to general deterrence than certainty of being detected and sanctioned. W. LAFAVE \& A. ScoTT, supra note 37 , at 25 \& n.31; E. Puitrammer, Administration of Criminal Law 16-19 (1953). In fact, exceptionally severe sanctions may be counterproductive, reducing the likelihood of sanctions being imposed. See E. PUTTKAMMER, supta, at 18.

57. This is where the problem of overdeterrence arises. Aggressive representation of the client's interests, a premise of the adversary system, can resemble Rule 11's "improper purpose." In addition, under our system of notice pleading and ample opportunity for discovery, insufficiency of facts in pleadings is sometimes expected. Perhaps most important, the line between a creative and a frivolous legal argument can be thin indeed. See sources cited supra note 6. Because Rule 11 operates against this backdrop, it should be aimed at achieving optimal rather than maximal general deterrence. $C f$. Cavanagh, Detrebling Antitrust Damages: An Idea Whose Time Has Come?, 61 Tul. L. Rev. 777, 801 (1987) (noting possibility of overdeterrence).

58. For a case implementing this approach, see Anschutz Petroleum Mktg. v. E.W. Saybolt \& Co., 112 F.R.D. 355 (S.D.N.Y. 1986). But cf. Parness, More Stringent Sanctions Under Federal Civil Rule 11: A Reply to Professor Nelken, 75 GEO. L.J. 1937, 1938-39 (1987) (suggesting that "[p]unishment, compensation, and deterrence may all serve as objectives of rule 11" and recommending that "trial judges should be responsible for expressly articulating . . . the purpose(s) of the sanctions imposed").

59. But see Schwarzer, supra note 5, at 1013 (identifying "the lack of predictability of the stan- 
consistently read an objective standard of sanctionable conduct into the Rule, ${ }^{60}$ and appellate courts frequently have synthesized disparate interpretations within a circuit by reviewing these determinations de novo. ${ }^{61}$ Even so, several commentators have proposed frameworks aimed at making determinations of when sanctionable conduct occurs more uniform. ${ }^{62}$ Since this aspect of Rule 11 has been the focus of most commentary and proposals for uniformity, this Note will focus on the other two interpretive questions.

In deciding whom to sanction, courts have rarely discussed their rationales. ${ }^{63}$ In the absence of guidance, many judges sanction the person whose signature is on the offending paper-namely, the attorney. Others decide whom to sanction without explanation. ${ }^{64}$ Some judges sanction the "party," without apportioning the sanction. ${ }^{65}$ Occasionally courts have sanctioned only the client. ${ }^{66}$ In most Rule 11 cases, judges have sanctioned either the attorney alone, ${ }^{67}$ or both attorney and client.

For Rule 11 to achieve its deterrent aims, the party responsible for the frivolousness of the pleading must be sanctioned. This will sometimes require a detailed investigation by the judge, which cannot be avoided if sanctions are to be properly imposed. However, judges, not wanting to make a more detailed inquiry into relative fault, often leave apportionment to attorney and client. Joint and several sanctions on attorney and client provide the clearest example of judicial failure to place sanctions squarely on the responsible parties based upon relative fault. ${ }^{68}$ Were Rule 11's primary goal compensation rather than deterrence, this might be preferable as a matter of policy. ${ }^{69}$ As it is, joint and several sanctions both

dard of compliance" as one of two major problems with Rule 11's current operation).

60. See NEw YoRK REPORT, supra note 4, at 13.

61. See sources cited infra note 78 .

62. See, e.g., Cavanagh, Developing Standards Under Amended Rule 11 of the Federal Rules of Civil Procedure, 14 Horstra L. REv. 499, 536-46 (1986); Note, supra note 6; see also Schwarzer, supra note 5 (suggesting courts focus on adequacy of inquiry rather than merits of pleading).

63. Nelken, supra note 6, at 1329. A partial exception to this silence is Judge Weinstein's opinion in Eastway Constr. Corp. v. City of New York, 637 F. Supp. 558, 569-70 (E.D.N.Y. 1986), modified, 821 F.2d 121 (2d Cir.), cert. denied, 108 S. Ct. 269 (1987).

64. See, e.g., Edwards v. Marsh, 644 F. Supp. 1564 (E.D. Mich. 1986) (court splits sanction evenly between client and attorney without giving reason).

65. These judges may harbor an outmoded agency conception of the attorney-client relationship. See infra note 90 .

66. See, e.g., Chevron, U.S.A. v. Hand, 763 F.2d 1184, 1187 (10th Cir. 1985). Many of the cases imposing sanctions on nonlawyers involve pro se litigants, particularly in taxpayer suits. E.g., Stites v. I.R.S., 793 F.2d 618 (5th Cir. 1986); Auen v. Sweeney, 109 F.R.D. 678 (N.D.N.Y. 1986). According to Professor Vairo, sanctioning only the client is rare. Vairo, supra note 11, at 227.

67. Courts have specifically sanctioned the offending attorney's firm-in one instance even though it had not been in existence throughout the entire frivolous litigation. See Calloway v. Marvel Entertainment Group, 650 F. Supp. 684 (S.D.N.Y. 1986).

68. See, e.g., Viola Sportswear, Inc. v. Mimun, 574 F. Supp. 619 (E.D.N.Y. 1983). Sanctions imposed jointly and severally on an attorney and her firm, however, might further Rule 11's deterrence goals by encouraging stricter oversight. See Calloway, 650 F. Supp. at 687.

69. See, e.g., Northern Trust Co. v. Muller, 616 F. Supp. 788 (N.D. Ill. 1985) (part of sanction imposed jointly and severally, reflecting compensation rationale). 
encourage private reallocation or "shifting" of sanctions, which can undercut deterrence, and damage the attorney-client relationship by creating conflict over how to apportion sanctions unapportioned by the court. ${ }^{70}$

As for the determination of what sanction to impose, courts have reached varying results. Rule 11 explicitly includes monetary sanctions as an option available to judges, ${ }^{71}$ and most reported sanctions have been monetary. Increasingly, however, nonmonetary sanctions are being imposed. Certain judges appear to favor monetary over nonmonetary sanctions, and vice versa. Thus, similarly situated violators could receive different types of sanctions depending upon the presiding judge's preferences. Judicial use of different methods to calculate monetary sanctions is a second source of disparity, injecting an element of arbitrariness into Rule 11 cases. ${ }^{72}$ Frequently, courts have imposed these monetary sanctions summarily, without any indication of how the amount was calculated. ${ }^{\text {s }}$ Some judges have imposed monetary sanctions based on "reasonable" attorneys' fees ${ }^{74}$ and costs. ${ }^{78}$ While some courts proceed to reduce this figure, ${ }^{76}$ not all consider the same factors in calculating reductions. Finally, numerous

70. For a general discussion of the potential threat to the attorney-client relationship posed by Rule 11 sanctions, see Eastway Constr. Corp. v. City of New York, 637 F. Supp. 558, 570 (E.D.N.Y. 1986), modified, 821 F.2d 121 (2d Cir.), cert. denied, 108 S. Ct. 269 (1987); Note, supra note 31, at 768-70.

71. Fed. R. Civ. P. 11.

72. See Parness, supra note 21 , at 1313 (noting disparities).

73. See, e.g., Woods v. Princeton Packaging, Inc., 655 F. Supp. 215, 218-19 (W.D. Wash. 1987). The Ninth Circuit overturned a $\$ 250,000$ lump sum sanction on the grounds that it was not "quantifiable with some precision and properly itemized in terms of the perceived misconduct and the sanctioning authority." In re Yagman, 796 F.2d 1165, 1184 (9th Cir.), amended, 803 F.2d 1085 (9th Cir. 1986), cert. denied, 108 S. Ct. 450 (1987).

74. For a discussion of fee calculation, see Breger, Compensation Formulas for Court Awarded Attorney Fees, 47 LAW \& ConTEMP. ProBs., Winter 1984, at 249, 249 (describing "absence of standards [and] .. . lack of uniformity among trial court fee awards"). Courts have recognized the need to bridle judicial discretion in other fee-setting contexts. See, e.g., Johnson v. Georgia Highway Express, Inc., 488 F.2d 714, 717-19 (5th Cir. 1974) (limiting discretion by setting out twelve factors judges must consider in calculating "reasonable" attorneys' fees under Title VII). That concepts such as the lodestar method have been used recently in calculating monetary sanctions under Rule 11 reflects the need for guidance on what sanctions are "appropriate." See Eastway, 637 F. Supp. at 571-72.

75. The term "costs" is statutorily defined in 28 U.S.C. $\$ 1920$ (1982). "Costs" refers to miscellaneous filing, duplication and witness costs incident to litigation, and are usually small compared to attorneys' fees.

A few courts have added to statutory costs and reasonable attorneys' fees the cost to taxpayers of the court's time spent on the frivolous filing, thus turning Rule 11 into a means of compensating the judicial system. See, e.g., National Ass'n of Radiation Survivors v. Turnage, 115 F.R.D. 543, 559 (N.D. Cal. 1987) (\$15,000 to be paid into court for "unnecessary consumption of the court's time and resources"). The cost of the court's time is usually calculated at $\$ 600$ per hour-a figure drawn from a recent law review article that calculated the average cost of an hour of a federal court's time. See Levin \& Colliers, Containing the Cost of Litigation, 37 Rutgers L. Rev. 219, 227 (1985). But see Edwards v. Marsh, 644 F. Supp. 1564, 1573 (E.D. Mich. 1986) (calculating court's time at $\$ 20$ per hour). One commentator has advocated the use of Rule 11 to compensate courts for their wasted resources. Parness, supra note 14 , at 352-62.

76. See, e.g., Eastway Constr. Corp. v. City of New York, 637 F. Supp. 558, 572-75 (E.D.N.Y. 1986) (specifying six mitigating factors), modified, 821 F.2d 121 (2d Cir.), cert. denied, 108 S. Ct. 269 (1987). 
judges have imposed "fines" under Rule 11-monetary sanctions unrelated to expense incurred and reflecting a punitive rationale. ${ }^{77}$

\section{B. Failures in Appellate Synthesis}

Appellate courts have applied different standards of review to the three interpretive issues raised by Rule 11 . Because Rule 11 requires judges to sanction specified types of proscribed conduct, the "when" question has been considered by most appeals courts to be a question of law and reviewed on a de novo basis. ${ }^{78}$ By contrast, all appeals courts have considered the "who" and "what" questions to be matters within the discretion of the trial judge, and therefore reviewable only on an "abuse of discretion" standard. Thus, while divergent answers to the first question have enjoyed a measure of appellate synthesis ${ }^{79}$ courts of appeals have less frequently reviewed answers to the second and third queries, and then only to define the outer parameters of discretion. District courts lack appellate guidance to fill the vacuum left by the Advisory Committee Notes and the language of the Rule itself. ${ }^{80}$

\section{The Benefits of a Uniform Conception of Rule 11}

Judicial acceptance of this Note's overall conception of Rule 11-including the Rule's primary deterrence purpose and its three, interrelated components-would promote uniformity in Rule 11 sanctions. In addition, the guidelines and factors described in Section V could provide needed direction to trial judges deciding whom to sanction and what sanction is appropriate. Guidelines have been used in other contexts to channel the exercise of a trial judge's discretion. ${ }^{81}$ While restrictive of judicial

77. See, e.g., Robinson v. Moses, 644 F. Supp. 975, 982-83 (N.D. Ind. 1986) (\$3600 fine in addition to costs and attorneys' fees); Blocker v. Oil \& Marine Corp., 113 F.R.D. 55, 59-60 (E.D. La. 1986) ( $\$ 7500$ fine). For a discussion of the problematic nature of such fines, see supra note 52 and accompanying text.

78. See, e.g., Donaldson v. Clark, 819 F.2d 1551, 1556 (11th Cir. 1987) (en banc); Zaldivar v. City of Los Angeles, 780 F.2d 823, 828 (9th Cir. 1986). Some circuits, including the Fourth and Tenth, review the question of when conduct is sanctionable on an abuse of discretion standard. See generally Vairo, supra note 11, at 225-27; Note, Rule 11 Sanctions: Contrasting Applications in the Second and Fourth Circuits, 46 MD. L. REv. 470 (1987). The Fifth Circuit recently abandoned de novo review in favor of the abuse of discretion standard. Thomas v. Capital Sec. Servs., 836 F.2d 866 (5th Cir. 1988) (en banc).

79. See cases cited supra note 78 .

80. The structure of Rule 11-mandating the imposition of sanctions when violations occur, but leaving wide discretion to set the kind and amount of sanction-presents heightened opportunities for strategic and interactive decisionmaking on the part of judges in this controversial area of law. See, e.g., Eastway Constr. Corp. v. City of New York, 762 F.2d 243 (2d Cir. 1985) (reversing Chief Judge Weinstein's determination that Rule 11 had not been violated), on remand, $637 \mathrm{~F}$. Supp. 558, 576-84 (E.D.N.Y. 1986) (imposing minimal sanction of $\$ 1,000$ ), modified, 821 F.2d 121 (2d Cir.) (raising amount of sanction to $\$ 10,000$ and summarily imposing it rather than remanding for adjustment), cert. denied, 108 S. Ct. 269 (1987).

81. In the federal sentencing area, a commission created pursuant to the Comprehensive Crime Control Act of 1984, Pub. L. No. 98-473, $\S 991,98$ Stat. 1837, 2017 (codified at 28 U.S.C. $\S 991$

(Supp. III 1985)), has promulgated sentencing guidelines aimed at increasing the uniformity of crimi- 
flexibility, guidelines offer numerous benefits, ${ }^{82}$ including better notice, increased fairness and efficiency, and most importantly, optimal deterrence.

Fairness requires the legal system to apply uniform standards to those who are similarly situated. Guidelines that address whom to sanction and factors to be weighed in determining appropriate sanctions are especially needed to ensure equal treatment under Rule 11, since a major argument undercutting the Rule's legitimacy has been that disagreement among judges has produced widely disparate results. ${ }^{83}$ Moreover, such guidelines would provide better notice to lawyers and clients about their respective areas of responsibility for frivolous submissions, ${ }^{84}$ and increase judicial efficiency in administering Rule 11 cases. $^{85}$

Nonuniformity in the method of calculating Rule 11 sanctions can seriously undermine the Rule's primary purpose of deterrence. As those studying the problem of indeterminacy in the area of sentencing reform have recognized, treating similarly situated defendants differently may create unfair results or undercut the deterrent effect of criminalizing conduct. ${ }^{86}$ In criminal sentencing, uniform treatment of similarly situated offenders has come to be seen as fairer, more effective, and more efficient than individualized judgments about individual offenders. ${ }^{\mathbf{8 7}}$

As applied today, Rule 11 probably both underdeters and overdeters. For example, it may overdeter plaintiffs' lawyers who often work on a contingency fee basis and who may be unwilling to pursue an innovative legal claim for fear of incurring a massive sanction. ${ }^{88}$ On the other hand,

nal sentences. See U.S. Sentencing Comm'n, Federal Sentencing Guideline Manual, 2 (West 1987); Robinson, supra note 35.

82. See generally Friendly, supra note 30 , at 768 .

83. See, e.g., S. KASSIN, supra note 4, at 45 (criticizing inconsistent standards in application).

84. To facilitate giving notice to clients (who are not required under Rule 11 to sign and certify submissions), lawyers could be obligated to inform their clients of the areas of client liability for Rule 11 sanctions. The Eleventh Circuit has recently noted that while the mere existence of Rule 11 usually will provide attorneys with adequate notice, when client sanctions are contemplated, "due process will demand more specific notice." Donaldson v. Clark, 819 F.2d 1551, 1560 (11th Gir. 1987) (en banc).

85. By providing greater certainty and predictability to litigants, guidelines would probably reduce the total amount of Rule 11 litigation. See Brown v. Federation of State Medical Bds. of the United States, 830 F.2d 1429, 1440 (7th Cir. 1987).

86. Robinson, supra note 35 , at 8 .

87. For the argument that certainty produces greater deterrence, see Nagel, Discretion in the Criminal Justice System: Analyzing, Channeling, Reducing, and Controlling It, 31 EMORY L.J. 603, 603-04 (1982); Robinson, supra note 35, at 8.

The major arguments leveled against sentencing reform claims to greater deterrence-that low probabilities of apprehension and conviction, and the possibility of parole, undermine the deterrent value of uniform sentences-do not apply in the Rule 11 context. Undetected Rule 11 abuses are far less likely than undetected crimes because opposing lawyers have a built-in incentive to move for sanctions, and judges are explicitly empowered to raise the issue sua sponte. See generally J. Andenaes, Punishment and Deterrence 34-65 (1974) (discussing factors influencing general deterrent effect of criminal sanctions); F. ZimRing \& G. Hawkins, supra note 56, at 92-209 (same).

88. Rule 11 provides that monetary sanctions, if imposed, may be based on "the amount of the reasonable expenses incurred because of the filing ...." FED. R. Crv. P. 11. This formula increases the likelihood that plaintiffs' lawyers will suffer high monetary sanctions, particularly since many 
the Rule probably underdeters defense counsel in large firms representing wealthy individuals or corporations. These lawyers and their clients might agree to risk Rule 11 sanctions, for example, in order to delay a judgment, particularly if there is a chance that only a minimal sanction will be imposed. Moreover, defense counsel in large firms often can surreptitiously shift sanctions onto clients, particularly onto longstanding ones. ${ }^{89}$ In both of these contexts, a more uniform method of calculating and imposing sanctions, which takes account of the differential need to deter and is buttressed by safeguards against shifting, would optimize deterrence.

\section{Guidelines for the Neglected Components}

\section{A. Whom to Sanction?}

Case law indicates that the decision of whom to sanction under Rule 11 often depends upon which type of sanctionable conduct has occurred. While judges have not expressly analyzed the question of whom to sanction in these terms, the case law does suggest that different criteria are determinative for each type of violation. The following guidelines have an empirical as well as a normative component: They incorporate as well as extend the case law.

\section{Submissions Not Warranted by Existing Law}

Usually the attorney should bear sole responsibility for submitting a pleading or motion not warranted by law in violation of Rule $11 .^{90}$ Normally a client will not be in a position to judge the validity of, ${ }^{91}$ or to urge her lawyer to make, unwarranted legal claims. ${ }^{92}$ Since legally frivolous violations comprise a large percentage of Rule 11 cases, handling them

Rule 11 sanctions are imposed for complaints. Complaints may provoke time-consuming dismissal or summary judgment motions as well as costly discovery proseedings. On the other hand, defense attorneys are most often sanctioned for motions.

89. For a discussion of the problem of sanction shifting, see infra Section V-B-2.

90. See, e.g., Muthig v. Brant Point Nantucket, Inc., 838 F.2d 600, 607 (1st Cir. 1988) (nonlawyer clients should not be expected to understand law); Blake v. National Casualty Co., 607 F. Supp. 189, 193 (C.D. Cal. 1984). Occasionally courts have imposed sanctions for legally frivolous submissions on both attorney and client. See, e.g., Shaps v. D.F.D.S. A/F Copenhagen, 1 Fed. R. Serv. 3d (Callaghan) 134 (S.D.N.Y. 1985). This approach reflects either a compensation rationale or a traditional agency conception of the attorney-client relationship. The agency theory justifies holding the principal at least partly liable for the agent's acts and omissions. See R. Rodes, K. RIPPLE \& C. Mooney, Sanctions Imposable for Violations of the Federal Rules of Civil. Procedure 70-73 (Federal Judicial Center 1981).

91. See Note, The Dynamics of Rule 11, supra note 17, at $331 \mathrm{n} .228$ (sanctionable conduct more often attorney's than client's).

92. A few courts have considered the client's legal sophistication a reason for holding him at least partially liable for sanctions. See, e.g., Thrush v. Morrison, 665 F. Supp. 372, 376 (M.D. Pa. 1987) $(\$ 6,000$ sanction imposed jointly and severally on attorney and on client who was "no stranger to the law"). But even if a legally sophisticated client knowingly urges her lawyer to advocate legally frivolous positions, the lawyer should bear the sanctions because he can more easily avoid the cost that an unwarranted legal submission imposes on the legal system and the opposing party. 
summarily by applying a rule of attorney liability will contribute to a more efficient overall application of the Rule.

Courts are just beginning to address the difficult question of how to allocate sanctions among multiple attorneys who participate in preparing the legally frivolous submission. ${ }^{93}$ These cases are rapidly changing the duties of cooperating lawyers under Rule $11 .^{94}$ In general, judges should sanction only the attorney who has prepared the legally frivolous submission. ${ }^{95}$

\section{Submissions Not Well Grounded in Fact}

Under this prong of Rule 11, courts are defining, in piecemeal fashion, the division of responsibilities between attorney and client. At risk of drawing sanctions are submissions that either contain untrue facts, or omit facts that are or should be within the knowledge of the filing party. ${ }^{96}$ Because the Rule explicitly imposes a duty upon the certifying attorney to make a reasonable prefiling inquiry into the factual basis and to certify that a submission is "well grounded" in fact, courts often have held the lawyer liable for factually frivolous submissions. On the other hand, many of these cases involve clients who provide their attorneys with false facts that form the basis of the attorney's submissions.

Courts generally will have to make a more detailed inquiry into responsibility for factually frivolous pleadings than for other types of violations. If a client knowingly provides false facts, ${ }^{97}$ or provides facts that the client should have known were false, then the client should be sanctioned. ${ }^{98}$ Clients should not be sanctioned, however, when the attorney fails to ask the

93. See, e.g., Itel Containers Int'l Corp. v. Puerto Rico Marine Mgmt., 108 F.R.D. 96, 102-05 (D.N.J. 1985); Navarro v. Cohan, 109 F.R.D. 86 (S.D. Fla. 1985) (partner sanctioned for associate's frivolous pleading).

94. Compare Coburn Optical Indus. v. Cilco, Inc., 610 F. Supp. 656, 660 n.7 (M.D.N.C. 1985) (local counsel may sometimes rely on "representations of reputable out of state attorneys") with Pravic v. U.S. Industries-Clearing, 109 F.R.D. 620, 623 (E.D. Mich. 1986) (cautioning that "an attorney may not rely on a legal memorandum prepared by a second lawyer without independently verifying the reasoning [or] 'Shepardizing' the cases cited") and Long v. Quantex Resources, Inc., 108 F.R.D. 416 (S.D.N.Y. 1985) (local counsel sanctioned for filing facially frivolous papers prepared by foreign counsel).

95. Usually local counsel alone should be sanctioned for procedural errors because of local counsel's obvious expertise in this area. In addition, judges should read the signature by local counsel as binding on lead counsel, see, e.g., AM Int'l, Inc. v. Eastman Kodak Co., No. 80 C 4016 (N.D. Ill. June 27, 1984) (LEXIS, Genfed library, Dist file), and hold the latter responsible for all substantive legal frivolousness. Cf. Monument Builders v. American Cemetery Ass'n, 647 F. Supp. 972 (D. Kan. 1986) (sanctions against local counsel shifted to primary counsel where local counsel came in after filing and did not prepare papers).

96. In keeping with our system of notice pleading, courts have been careful not to sanction for complaints that omit facts in the adversary's control. See Oliveri v. Thompson, 803 F.2d 1265, 1279 (2d Cir. 1986), cert. denied, $107 \mathrm{~S}$. Ct. 1373 (1987). For the argument that Rule 11 may have altered the factual pleading requirements under FED. R. Giv. P. 8, see Vairo, supra note 11, at 220.

97. See, e.g., Kappenberger v. Oates, 663 F. Supp. 991, 995 (S.D.N.Y. 1987).

98. Holding the attorney liable in such a case would fail to deter the dishonest client and would encourage excessive investigation of the client's story. This could erode the attorney-client relationship. 
right questions to elicit legally relevant facts. ${ }^{89}$ In addition, the attorney should be sanctioned for failure to take minimal steps to confirm the client's facts, when these facts could be verified easily by reference to the public record or to accessible documents. ${ }^{100}$

\section{Submissions Interposed for an Improper Purpose}

Lawyers frequently have been sanctioned for improper purpose violations. ${ }^{101}$ Often, however, courts have without explanation simply sanctioned both attorney and client for these kinds of violations, apparently on the belief that somehow attorney and client shared the improper purpose. Courts should generally place responsibility for improper purpose violations on the lawyer since she exercises primary control over the litigation. Sanctioning the attorney will create an incentive for the attorney to second-guess the client in matters of legal strategy-the result that should be fostered. ${ }^{102}$ Ultimately, it is the attorney who, as an officer of the court, must ensure that the court's processes are not abused.

Courts should scrutinize two types of filings, however, as potentially warranting client sanctions under the improper purpose prong of Rule 11: re-filed complaints and post-judgment motions filed by clients who have retained new lawyers. Courts could handle such re-filed complaints in several ways. ${ }^{103}$ They could require attorneys to investigate the past litigation record of new clients and sanction attorneys who could have discovered that a client's prior identical complaint had been dismissed. Alterna-

99. See, e.g., Unioil, Inc. v. E.F. Hutton \& Co., 809 F.2d 548 (9th Cir. 1986), cert. denied, 108 S. Ct. 85 (1987). The Rule states that an attorney has a duty to make a "reasonable inquiry" into the factual basis for a submission. An ABA study of Rule 11 and other sanctions in federal courts advises attorneys to "[c]onduct a thorough personal interview with [their] client and key witnesses about the pleading," as well as to "[r]eview pertinent documents that may support the pleading." ABA REPORT, supra note 7 , at 25 .

100. For example, in Van Berkel v. Fox Farm \& Road Mach., 581 F. Supp. 1248 (D. Minn. 1984), the attorney was sanctioned for not checking relevant medical records which would have revealed that the statute of limitations had run. But see Kamen v. American Tel. \& Tel., 791 F.2d 1006, 1012 (2d Cir. 1986) (attorney reasonably relied on client's statements that client's employer received federal military grants).

Like the duty to make a "reasonable inquiry" into the facts, the attorney's duty to check public records would not impinge on the attorney-client relationship. See also Oliveri, 803 F.2d at 1265, 1277-78 (attorney must take reasonable steps to verify client's information but need not pass judgment on client's credibility); Advisory Notes, supra note 6, at 199.

101. The court in In re TCI Ltd., 769 F.2d 441 (7th Cir. 1985), affirmed the imposition of sanctions on a bankruptcy lawyer for filing frivolous claims aimed at delaying the implementation of an agreed-upon bankruptcy settlement. Judge Easterbrook rejected the lawyer's defense that he had filed the submissions at the insistence of his client. Id. at 446. Similarly, the court in Mohammed $v$. Union Carbide Corp. observed, "[a]n attorney is obligated to dissuade his client from pursuing specious claims." 606 F. Supp. 252, 261 (E.D. Mich. 1985).

102. The danger to attorney-client relations under this branch of Rule $\mathbf{1 1}$ is not nearly as great as under the factual branch. See supra note 98.

103. McLaughlin v. Bradlee, 803 F.2d 1197 (D.C. Cir. 1986), illustrates the repeat litigant scenario. In McLaughlin, the plaintiff brought four successive, roughly identical suits over a seven-year period. After losing in one court, the plaintiff simply refiled in another. See also Becker v. Dunkin' Donuts of Am., 665 F. Supp. 211 (S.D.N.Y. 1987) (failed applicant filed latest of dozens of employment suits). 
tively, courts could analyze these cases under the insufficient-as-of-law element and sanction the attorney because the complaint was barred by res judicata. These approaches are problematic because in most of these cases the client, and not the attorney, is the moving force. To impose sanctions on attorneys would not deter the client. On the other hand, when the same attorney remains with the repeat litigant throughout an entire campaign of harassment, ${ }^{104}$ or a new attorney is put on notice of the history of frivolous litigation, ${ }^{105}$ the court should allocate sanctions evenly between attorney and client, based on a presumption of equal fault.

Post-judgment motions interposed for an improper purpose ${ }^{106}$ also call for client sanctions, at least where the client changes attorneys after a settlement is reached or the case concluded. Only by placing the sanction on the client will courts deter this type of abuse. Frivolous post-judgment motions by the same attorney who tried the case should fall on the attorney, however.

\section{B. What Sanction is "Appropriate"?}

Because Rule 11 leaves the choice of sanction entirely to the trial judge's discretion, judges have employed widely divergent approaches unrelated to the need to deter the offending party. To increase uniformity, trial judges should consider various factors in setting monetary sanctions and ensure that monetary sanctions are not passed on to innocent parties. Appellate courts should review decisions about what sanction is appropriate under a heightened abuse of discretion standard.

\section{Factors To Be Used by Judges in Determining Monetary Sanctions}

In calculating monetary sanctions, courts have considered different factors, including the sanctioned person's limited resources, ${ }^{107}$ the nature of the plaintiff's claims, ${ }^{108}$ and the need to compensate a party for expenses.

104. E.g., Lee v. Criterion Ins. Co., 659 F. Supp. 813 (S.D. Ga. 1987) (plaintiff's attorney sanctioned when continued second suit after initial suit was lost).

105. See, e.g., Charlton v. Estate of Charlton, 2 Fed. R. Serv. 3d (Callaghan) 596 (D. Ariz. 1985).

106. For example, in Chevron v. Hand, 763 F.2d 1184 (10th Cir. 1985), the defendant filed a Rule 60 (b) motion attempting to set aside a judgment after her original attorney had entered into a stipulation to which she had agreed. The court directly sanctioned defendant for a frivolous Rule 60(b) motion aimed solely at delaying the judgment.

107. E.g., Dunkin' Donuts, 665 F. Supp. at 218. Courts have also considered the sanctioned person's net worth a reason for not reducing a sanctions award. E.g., Eppes v. Snowden, 656 F.Supp. 1267 (E.D. Ky. 1986) (\$194,000 sanction).

108. See, e.g., Szabo Food Serv. v. Canteen Corp., 823 F.2d 1073, 1085-86 (7th Cir. 1987) (Cudahy, J., concurring in part and dissenting in part) (civil rights plaintiff claiming violation of due process should be accorded greater leeway in making arguments), cert. dismissed, $108 \mathrm{~S}$. Ct. 1101 (1988); O'Rourke v. City of Norman, 640 F. Supp. 1451 (W.D. Okla. 1986). But see Oliveri v. Thompson, 803 F.2d 1265, 1280 (2d Cir. 1986) (rejecting argument that "special treatment of sanctions should be given to attorneys who handle unpopular civil rights claims, particularly those representing indigents and minority clients"), cert. denied, 107 S. Ct. 1373 (1987). 
Other courts have deemed the requested fees inflated, ${ }^{109}$ or invoked a "duty to mitigate" 120 to reduce the cost of legal fees incurred by the opposite side, implying that opposing counsel spent too much time opposing a frivolous paper. ${ }^{111}$ Occasionally courts have increased the amount of a monetary sanction where the offending attorney or her firm is expert in a particular area.

There is already a trend towards requiring district judges to specify the grounds for deciding which sanction to impose, ${ }^{112}$ and appellate courts have sometimes reversed monetary sanctions for lack of specification. ${ }^{113}$ In keeping with this trend, judges should consider specific factors in setting monetary Rule 11 sanctions. ${ }^{114}$ The base figure should be calculated according to a uniform method, ${ }^{115}$ based on cost incurred by the opposing side but not on court costs. ${ }^{116}$ This method of initial calculation acknowledges that Rule 11, though aimed primarily at deterrence, also includes a compensatory purpose. Judges should then reduce this figure to achieve the Rule's primary purpose of deterrence. ${ }^{117}$ In reducing monetary sanctions, judges should consider six factors: ${ }^{118}$

109. See, e.g., McIntyre's Mini Computer Sales Group v. Creative Synergy Corp., 644 F. Supp. 589,593 (E.D. Mich. 1986) (calling amount of requested fees "astounding").

110. See, e.g., In re Yagman, 796 F.2d 1165, 1185 (9th Cir.), amended, 803 F.2d 1085 (9th Cir. 1986), cert. denied, 108 S. Ct. 450 (1987).

111. See, e.g., Cleveland Demolition Co. v. Azcon Scrap Corp., 827 F.2d 984, 988 (4th Gir. 1987) (upholding district court's reduction of attorneys' fees by $10 \%$ due to overlawyering); Wolst v. American Airlines, 668 F. Supp. 1117, 1120 n.1 (N.D. Ill. 1987) (criticizing attorney requesting fees for including time for self-education).

112. See, e.g., Brown v. Federation of State Medical Bds. of the United States, 830 F.2d 1429, 1438 (7th Cir. 1987) ("II]n cases involving substantial awards a district judge [must] state with some specificity the reasons for the imposition of a sanction, and the manner in which the sanction was computed.") (emphasis added). But see Thomas v. Capital Sec. Servs., 836 F.2d 866, 882-83 (5th Cir. 1988) (en banc) (requiring specific findings of district court only when sanctions imposed are substantial in type, amount, or effect).

113. See, e.g., Cauley v. Wilson, 754 F.2d 769, 772 (7th Cir. 1985). But see Ordower v. Feldman, 826 F.2d 1569, 1576 (7th Cir. 1987). See also Brown, 830 F.2d at 1440 (requiring specification of basis for finding Rule violated). Requiring such specification will probably not consume more judicial resources of trial courts, since fewer remands will occur. Id. at 1438.

114. These factors might also be useful in choosing between monetary and nonmonetary sanctions, or among various nonmonetary sanctions. Since most sanctions under Rule 11 are monetary, the enumerated factors will be aimed at the determination of monetary awards.

115. In Eastway Constr. Corp. v. City of New York, 821 F.2d 121, 124-26 (2d Cir.) (dissenting opinion), cert. denied, 108 S. Ct. 269 (1987), Judge Pratt, in dissent, recognized the need for a uniform method of calculating Rule 11 sanctions that were purportedly based on attorneys' fees. He argued that the lodestar figure should be the starting point, and that judges should consider only the financial resources of the sanctioned person in deciding whether to reduce the award.

116. Professor Nelken has proposed limiting monetary sanctions to the costs and fees incurred by opposing parties. Nelken, supra note 6, at 1353. Contra Parness, supra note 58, at 1941-42 (arguing that Nelken's suggestion may render monetary sanctions ineffective where sanctioned party's conduct is especially egregious, cost incurred is small, or both parties have violated Rule). Nelken's proposal makes sense given the danger of overdeterrence. See supra note 57 and accompanying text. Parness overlooks the possibility of adding nonmonetary sanctions to monetary awards in these circumstances.

117. Occasionally deterrence will require adding nonmonetary sanctions onto this base monetary amount.

118. This list builds on Chief Judge Weinstein's analysis in Eastway, 637 F. Supp. at 572-75. In modifying, the Second Circuit specifically declined to rule on the appropriateness of Weinstein's factors. Eastway, 821 F.2d at 123. 
(1) The violator's general bad faith or vindictive desire to punish the opponent.

(2) The degree of frivolousness.

These first two factors address the degree to which the violator has abused the court's processes and thus may be directly relevant to the amount and kind of sanction necessary to achieve specific deterrence. ${ }^{119}$

(3) The violator's ability to pay.

Obviously, the sanctioned person's ability to pay will have an effect on the deterrent value of any given sanction: the poorer the target, the greater the deterrence achieved. ${ }^{120}$

(4) The violator's level of experience and general reputation.

If the violator is inexperienced, a smaller sanction may suffice to achieve deterrence. ${ }^{121}$

(5) The importance of not discouraging particular types of litigation.

Deterrence can only be achieved meaningfully against the backdrop of congressionally created disincentives and incentives for litigants. If Congress has expressed a clear preference for encouraging particular types of litigants by enacting a fee-shifting statute, then courts should reduce the monetary sanction. Thus, civil rights plaintiffs or others suing under statutes that provide for fee-shifting should have this mitigating factor considered. ${ }^{122}$

(6) The fee basis of representation.

In deciding how much deterrence a particular monetary sanction will produce, courts should consider the fee basis underlying the representation. Defense attorneys, who work on an hourly fee basis, will generally be able to pay monetary sanctions out of their billings, subject to market constraints on their fee rates. On the other hand, plaintiffs' attorneys who operate on a contingent fee basis may not have such billings to use to pay monetary sanctions. Thus, all else being equal, the same monetary sanction imposed on a plaintiff's attorney working on a contingent fee basis will have more of a deterrent effect. This consideration is related to the ability to pay factor. After considering all of the foregoing factors, judges should set the monetary sanction so that the violator is neither over- nor underdeterred.

This Note's list of six factors includes five of Chief Judge Weinstein's. It omits the need to compensate as a separate factor because compensatory goals are already reflected in the calculation of the sanction's base. The Note's sixth factor, which concerns the fee basis of representation, will be relevant to deterrence in cases where attorneys are sanctioned.

119. See Advisory Notes, supra note 6, at 200 (judge should consider violator's state of mind in setting type and amount of sanction).

120. See, e.g., Kappenberger v. Oates, 663 F. Supp. 991, 994 (S.D.N.Y. 1987).

121. See Schwarzer, supra note 10 , at 201.

122. See cases cited supra note 108. 


\section{Avoiding the Shifting Problem}

If lawyers or clients are able to shift sanctions onto innocent parties, Rule 11's specific deterrent effect will largely be lost. ${ }^{123}$ To the extent that sanctions harm a lawyer's reputation, of course, they cannot be shifted onto clients. The vast majority of Rule 11 sanctions, however, contain some shiftable element. ${ }^{124}$

Joint and several sanctions pose special problems, because they actually encourage private shifting of sanctions. Even when courts impose sanctions on both attorney and client (but not jointly and severally), informal shifting may occur unless the court explicitly bars it. Shifting in any form enables attorneys and clients to undo the court's assignment of relative fault.

Courts are only beginning to tailor monetary sanctions so that they cannot be shifted. A small but growing number of Rule 11 cases have contained outright directives against shifting. ${ }^{128}$ Courts could easily incorporate such anti-shifting directives in their opinions. A more effective way to prevent shifting would be to amend the Rule to incorporate an explicit ban on shifting. ${ }^{126}$ In addition, courts could require attorneys to give their clients a copy of the sanction order. ${ }^{127}$

\section{Review Under a "Heightened" Abuse of Discretion Standard}

The abuse of discretion standard is subject to wide interpretation. ${ }^{128}$ This disparity is not necessarily a bad thing; indeed, according to Judge

123. The problem of shifting Rule 11 sanctions has received only passing mention in the literature. See, e.g., Peckham, The Federal Judge as a Case Manager: The New Role in Guiding a Case from Filing to Disposition, 69 GALIF. L. REV. 770, 802 (1981); Note, The Dynamics of Rule 11, supra note 17, at 331 n.228; Note, Intended Application, supra note 17, at 353-54.

124. Perhaps the only exceptions are oral or written reprimands and disciplinary proceedings. An attorney's costs in defending herself in disciplinary proceedings could, at least conceivably, be shifted onto a longstanding client.

Most Rule 11 sanctions have been monetary, a kind of sanction particulary susceptible to shifting. For a discussion of whether Rule 11 sanctions might be covered by legal malpractice policies, see Hamilton, McKee \& Levitt, Insurability of Monetary Sanctions Under Attorney Errors and Omissions Policies, 54 Def. Couns. J. 520 (1987).

125. See, e.g., Motown Prods. v. Cacomm, Inc., 668 F. Supp. 285 (S.D.N.Y. 1987). In Wold v. Minerals Eng'g Co., 575 F. Supp. 166 (D. Colo. 1983), the court ordered defendant's attorneys to pay sanctions to plaintiff with the stipulation that "payment of these expenses shall not be reimbursed directly or indirectly from the funds, assets or resources of [defendant] itself." Id. at 168; see also Hatteras of Lauderdale, Inc. v. Gemini Lady, 662 F. Supp. 1525 (S.D. Fla. 1987).

126. A provision could be enacted much like the unadopted amendment to Rule 37, governing discovery sanctions, recommended in 1980 by an ABA Special Committee:

(g). Sanctions Against An Attorney. Whenever the court imposes a monetary sanction upon an attorney in accordance with these rules, the attorney or his firm shall satisfy such sanction and shall not, directly or indirectly, charge any portion of such sanction to his client or receive or accept any portion of such sanction from his client.

Section of Litigation, ABA, Second Report of the Special Committee for the Study of Discovery Abuse, 92 F.R.D. 137, 147-48 (1980) (italics in original).

127. See Peckham, supra note 123, at 802 . This would allow clients to guard against shifting and would thus enhance the deterrent effect of the sanction.

128. See Friendly, supra note 30, at 762-64, 783-84; Rosenberg, Judicial Discretion of the Trial 
Friendly, it may be "not only defensible but essential."129 The reasons for using a strict as opposed to a loose abuse of discretion standard will vary according to the nature of the decision..$^{130}$ More circuits should apply the most stringent "abuse of discretion" standard, thereby vigilantly monitoring district court exercise of discretion under Rule $11 .{ }^{131}$ This is beginning to happen in a few courts. ${ }^{132}$

\section{Conclusion}

Because amended Rule 11 gives the trial judge almost total discretion to determine whom to sanction and what sanction is "appropriate," sanctions under the Rule have varied widely. Certain judges have become known as frequent sanctioners, while others have only rarely imposed sanctions. Some have viewed sanctions primarily as a means of compensating litigants for costs incurred in defending against frivolous motions; others have employed the Rule more sparingly and primarily to punish. This Note has proposed a conceptual framework for viewing Rule 11, including a focus on deterrence and suggested guidelines and factors to trim the discretion of trial judges. The application of this framework will increase the uniformity of Rule 11 sanctions and optimize deterrence of frivolous litigation in the federal courts.

Court, Viewed from Above, 22 SyRACUSE L. REv. 635, 650-53 (1971). For example, trial judges are given almost unreviewable discretion to decide whether to grant a request to require the jury to render a special verdict under Rule 49(a), but their discretion to deny leave to amend under Rule 15(a) is more circumscribed. See Louis, Allocating Adjudicative Decision Making Authority Between the Trial and Appellate Levels, 64 N.C.L. REv. 993, 1039 (1986).

129. Friendly, supra note 30 , at 764.

130. See United States v. Criden, 648 F.2d 814, 817-18 (3d Cir. 1981) (while need for first-hand observation of litigants or newness and variability of circumstances may initially require deference to trial judge's decision, once factors important to making discretionary decision "emerge from the montage of fact patterns," as in attorneys' fee area generally, then less deference should be accorded).

131. But see Levin \& Sobel, supra note 7, at 600 (arguing that appellate courts have exercised their reviewing power in balanced fashion and that to give less respect to district court discretion could produce "intolerably burdensome proliferation of satellite litigation").

132. See, e.g., Eastway Constr. Corp. v. City of New York, 821 F.2d 121 (2d Cir.), cert. denied, 108 S. Ct. 269 (1987); Cheek v. Doe, 828 F.2d 395, 397 (7th Cir.) (finding \$10,500 sanction on pro se litigant abuse of discretion "particularly without a sufficient statement of reasons" and reducing sanction to \$5,000), cert. denied, 108 S. Ct. 349 (1987). 
